\title{
Kejadian Ikutan Pasca Imunisasi Vaksin Kombinasi DPwT (Sel Utuh) dan Hepatitis B
}

\author{
Diana Mettadewi Jong, Adji Suranto, Hartono Gunardi, Alan R Tumbelaka
}

\begin{abstract}
Indonesia merupakan wilayah dengan endemis tinggi hepatitis $\mathrm{B}$, maka vaksinasi hepatitis B (hep B) merupakan solusi terbaik untuk mencegah penyakit ini. Kombinasi hep B dengan DPwT (pertusis whole cell) = sel utuh dalam satu kemasan, memberikan kenyamanan pada pasien dan memudahkan pelayanan kesehatan. Di samping keuntungan ini, kejadian ikutan pasca imunisasi (KIPI) vaksin ini perlu diperhitungkan. Untuk mengetahui KIPI vaksin ini, dilakukan studi prospektif pada 74 bayi berumur 2-6 bulan di Bagian Ilmu Kesehatan Anak RSCM Jakarta antara Juli 2000 sampai dengan Maret 2001. Bayi-bayi tersebut diberi 3 dosis vaksin kombinasi DPT dan hep B (DPwT/hep B) dengan selang waktu 5 minggu. Kartu observasi harian terhadap gejala yang timbul selama 5 minggu pasca imunisasi diisi orangtua dan data dikumpulkan pada kunjungan berikutnya. Umumnya KIPI timbul kurang dalam 72 jam setelah pemberian vaksin. Frekuensi KIPI tersering adalah demam $(58,8 \%)$ diikuti oleh rewel $(31,7 \%)$ dan demam tinggi $(16,2 \%)$. Kejang umum timbul pada 1 kasus setelah pemberian dosis pertama dan pada 1 kasus lain kejang disertai demam tinggi. Setelah pemberian dosis ketiga pada kedua kasus tersebut, pasien mendapat antipiretik dan kejang berhenti tanpa pengobatan anti kejang. Tidak ditemukan KIPI pada vaksin DPwT/hep B yang memerlukan perawatan di rumah sakit. KIPI yang didapatkan umumnya bersifat ringan sampai sedang.
\end{abstract}

Kata kunci: kejadian ikutan pasca imunisasi, vaksin kombinasi, DPwT (DPwhole cell T), vaksin hepatitis $\mathrm{B}$.

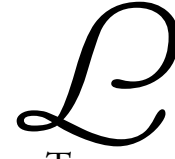
ebih kurang $45 \%$ penduduk dunia hidup di daerah dengan prevalensi hepatitis $B$ kronis tinggi. Di negara-negara Asia Tenggara dan Asia Timur diperkirakan 3-5 \% bayi akan menderita hepatitis B kronik pada saat lahir. ${ }^{1}$ Carrier rate hepatitis $\mathrm{B}$ yang ditunjukkan oleh $\mathrm{HBsAg}$ di Indonesia secara geografis bervariasi antara 5-20\%, dengan demikian Indonesia termasuk wilayah endemis tinggi/sedang. Vaksinasi hepatitis B dipastikan merupakan solusi terbaik untuk mencegah penyakit ini. ${ }^{2}$ Vaksin hepatitis B (hep B) merupakan vaksin mati,

Alamat korespondensi:

Dr. Diana Mettadewi Jong.

PPDS Bagian Ilmu Kesehatan Anak FKUI-RSCM. Jl. Salemba no. 6, Jakarta 10430 .

Telepon: 314 8610. Fax. 3913982. pertama kali diperkenalkan pada tahun 1981; sejak saat itu vaksin ini berkembang sangat pesat. ${ }^{1,3}$ Pada tahun 1997, WHO Expanded Program on Imunization (EPI) merekomendasikan vaksinasi hep B pada bayi-bayi di seluruh dunia. ${ }^{1}$ Sejalan dengan EPI, di Indonesia vaksin hep B termasuk dalam Program Pengembangan Imunisasi (PPI) pada tahun 1997.

Vaksinasi difteriA, tetanus dan pertusis (DPT) mulai dikenal di dunia pada tahun 1941. Vaksin ini mulai dilaksanakan di Indonesia sejak tahun 1976 dan merupakan vaksin PPI sejak tahun $1977 .{ }^{2}$ Komponen D dan T pada DPT merupakan toksoid dan komponen pertusis merupakan vaksin mati. Vaksin DPT yang berkembang sekarang meliputi DPwT (whole cell=sel utuh) dan DPaT (aseluler). ${ }^{4}$ Untuk kenyamanan pasien dan memudahkan pemberian serta distribusi vaksin, berbagai usaha telah 
dilakukan untuk mengembangkan vaksin kombinasi hep B dan DPT. Alasan kombinasi vaksin ini adalah masing-masing merupakan vaksin mati, direkomendasikan untuk bayi dan diberikan melalui suntikan dengan ulangan beberapa dosis. Jadwal imunisasi hep B bersifat fleksibel dan dapat disesuaikan dengan jadwal imunisasi DPT.,

Kemampuan proteksi hep B dan DPT dalam 1 kemasan dan prosedur menguntungkan orangtua dan pasien, karena jumlah suntikan dan kunjungan berkurang. ${ }^{7}$ Keuntungan ini membawa manfaat pelayanan kesehatan masyarakat berupa meningkatnya kepatuhan pasien, berkurangnya biaya pelayanan kesehatan, kemudahan penyimpanan dan pengiriman vaksin serta pencatatan data pasien. ${ }^{7-10}$ Di samping keuntungan-keuntungan ini, kejadian ikutan pasca imunisasi (KIPI) vaksin ini wajib diperhitungkan, apakah reaksi akibat vaksin ini terhadap KIPI. KIPI pada DPwT diketahui berhubungan dengan komponen vaksin pertusis, ${ }^{4}$ sedangkan KIPI pada hep B minimal. ${ }^{1,3}$ Tujuan penelitian ini untuk memberikan evaluasi kejadian ikutan pasca imunisasi vaksin kombinasi DPwT dan hep B pada anak Indonesia.

\section{Bahan dan Cara}

\section{Vaksin}

Vaksin kombinasi DPT (sel utuh) dan HB (DTPw/ HB) yang dipakai pada penelitian ini adalah TritanrixHB, yang diproduksi oleh Glaxo SmithKline. Satu dosis $(0,5 \mathrm{ml})$ vaksin mengandung toksoid difteri $\geq 30$ IU, toksoid tetanus $60 \mathrm{IU}$, bakteri pertusis mati sel utuh $\geq 4 \mathrm{IU}$ dan protein rekombinan HBsAg $10 \mu \mathrm{g}$ dengan 0,63 mg AL $\mathrm{AL}^{+++} 4,5 \mathrm{mg}$ natrium klorida, $25 \mu \mathrm{g}$ timerosal dan 50 Ïg fenoksietanol.

\section{Subjek}

Subjek penelitian ini adalah 74 bayi sehat yang datang ke Poliklinik Tumbuh Kembang RSCM pada periode Juli 2000-Maret 2001, berumur 2-6 bulan (9-31 minggu), belum pernah mendapat imunisasi DPT sebelumnya, tidak ada riwayat alergi terhadap komponen DPT atau $\mathrm{HB}$, tidak sedang menderita demam oleh sebab apapun, tidak sedang menderita penyakit berat, dan tidak ada riwayat kejang dalam 48 jam sesudah mendapat imunisasi lain sebelumnya.

\section{Cara penelitian}

Setelah orangtua membaca informasi, setuju menandatangani infomed consent, subyek penelitian ditentukan berdasarkan kriteria di atas oleh dokter. Semua vaksin disuntikkan secara intra muskular pada paha bagian anterolateral sebanyak 3 dosis dengan selang waktu 5 minggu antar dosis. Dilakukan observasi 15 menit pasca penyuntikan vaksin, pasien diperbolehkan pulang dan orangtua diwajibkan mengisi kartu observasi selama 5 minggu serta melaporkan pada kunjungan berikut. Kartu harian berisi informasi tentang semua reaksi lokal maupun sistemik yang timbul, saat timbul, lama reaksi dan terapi yang diberikan. Semua data yang terkumpul disajikan dalam tabel.

\section{Hasil Penelitian}

\section{Demografi}

Dari 74 bayi yang mengikuti penelitian, 67 bayi dapat menyelesaikan penelitian. Lima kasus tidak datang kembali setelah penyuntikan dosis pertama. Satu kasus timbul kejang setelah penyuntikan dosis pertama sehingga penyuntikan dosis berikutnya dihentikan. Satu kasus tidak datang kembali setelah penyuntikan dosis kedua. Berikut ini tertera Tabel 1 sebaran umur dan jenis kelamin populasi penelitian.

\section{KIPI}

Semua data yang terkumpul dianalisis terhadap KIPI, termasuk 7 bayi yang gagal menyelesaikan penelitian. Pada penelitian ini dipakai 209 dosis vaksin kombinasi. Satu kasus timbul kejang tonik klonik sebanyak 3 kali, selama 1-2 menit tiap kejang, terjadi lebih kurang 11,5 jam setelah penyuntikan dosis pertama. Jarak tiap kejang 1-2 jam, disertai demam tinggi. Pasca kejang pasien sadar dan tidak terdapat kelainan neurologik. Satu kasus lain timbul kejang umum, kedua mata mendelik ke atas, kedua lengan dan tungkai lemas, kejang 1 kali selama 5 menit pada lebih kurang 16 jam setelah pemberian dosis ketiga. Kejang disertai demam tinggi. Kedua pasien tersebut tidak mempunyai riwayat kejang sebelumnya dan telah diberi antipiretik. Kasus-kasus kejang tersebut berhenti tanpa pengobatan 
anti kejang.

KIPI tersering adalah demam $(59,2 \%)$, diikuti dengan rewel $(31,5 \%)$ dan demam tinggi $(16,1 \%)$. Gejala demam timbul pada 1-4 jam pertama $(56,7 \%)$ setelah diberi imunisasi. Lama gejala demam umumnya 1-4 jam (35,9\%). (Tabel 2, Tabel 3 dan Tabel 4)

Lebih kurang lima puluh persen dari kejadian demam tinggi timbul setelah 1-4 jam pemberian vaksin

Tabel 1. Sebaran umur dan jenis kelamin

\begin{tabular}{lcccc}
\hline Jenis Kelamin & $\mathrm{n}$ & $\begin{array}{c}\text { Rata-rata umur } \\
(\text { minggu })\end{array}$ & $\begin{array}{c}\text { Umur terkecil } \\
(\text { minggu })\end{array}$ & $\begin{array}{c}\text { Umur terbesar } \\
(\text { minggu })\end{array}$ \\
\hline Laki-laki & 39 & 10,9 & 9 & 20 \\
Perempuan & 35 & 9,9 & 9 & 15 \\
\hline Total & 74 & 10,4 & 9 & 20
\end{tabular}

Tabel 2. KIPI setelah pemberian tiap dosis DPwT/hep B

\begin{tabular}{|c|c|c|c|c|}
\hline KIPI & $\begin{array}{c}\text { Dosis I } \\
\mathrm{n}=74 \\
(\%)\end{array}$ & $\begin{array}{c}\text { Dosis II } \\
\mathrm{n}=68 \\
(\%)\end{array}$ & $\begin{array}{c}\text { Dosis III } \\
\mathrm{n}=67 \\
(\%)\end{array}$ & $\begin{array}{c}\text { Total } \\
\mathrm{n}=29 \\
(\%)\end{array}$ \\
\hline Demam & 63,5 & 55,9 & 58,2 & 59,2 \\
\hline Demam tinggi* & 23,0 & 11,8 & 13,4 & 16,1 \\
\hline Rewel & 33,8 & 36,8 & 23,9 & 31,5 \\
\hline Muntah & 13,5 & 10,3 & 4,5 & 9,4 \\
\hline Diare & 6,8 & 4,4 & 1,5 & 4,2 \\
\hline \multicolumn{4}{|l|}{ Bengkak pada } & 9,0 \\
\hline $\begin{array}{l}\text { Nyeri lokal } \\
\text { tanpa bengkak }\end{array}$ & 1,4 & 0,0 & 0,0 & 0,5 \\
\hline Lemas & 4,1 & 2,9 & 10,4 & 5,8 \\
\hline $\begin{array}{l}\text { Bentol merah** } \\
\text { (urtikaria) }\end{array}$ & \multicolumn{3}{|c|}{ Bentol merah** } & 2,8 \\
\hline Kejang umum & $1,4^{\bullet}$ & 0,0 & $1,5 \bullet \bullet$ & 0,9 \\
\hline Pucat & 1,4 & 0,0 & 0,0 & 0,5 \\
\hline Keterangan: * & $\begin{array}{l}\text { bih dari } 3 \\
\text { ah di pipi, } \\
\text { pa kedua } \\
\text { k klonik } 3\end{array}$ & $\begin{array}{l}\text { \& kaki } \\
\text { endelik k } \\
\text { ama 1-2 n }\end{array}$ & $\begin{array}{l}\text { angan da } \\
\text { p kejang }\end{array}$ & $\begin{array}{l}\text { mas } \\
\text { itara kejanı }\end{array}$ \\
\hline
\end{tabular}

Tabel 3. Saat timbul gejala demam setelah pemberian tiap dosis DPwT/hep B

\begin{tabular}{lcccc}
\hline $\begin{array}{l}\text { Saat timbul } \\
\text { gejala demam } \\
\text { (jam) }\end{array}$ & $\begin{array}{c}\text { Dosis I } \\
\mathrm{n}=47 \\
(\%)\end{array}$ & $\begin{array}{c}\text { Dosis II } \\
\mathrm{n}=38 \\
(\%)\end{array}$ & $\begin{array}{c}\text { Dosis III } \\
\mathrm{n}=39 \\
(\%)\end{array}$ & $\begin{array}{c}\text { Total } \\
\mathrm{n}=124 \\
(\%)\end{array}$ \\
\hline$<1$ & 0,0 & 2,6 & 2,6 & 1,7 \\
$1-4$ & 63,8 & 50,0 & 56,4 & 56,7 \\
$5-12$ & 36,2 & 36,8 & 41,0 & 38,0 \\
$13-24$ & 0,0 & 5,3 & 0,0 & 1,8 \\
$25-48$ & 0,0 & 2,6 & 0,0 & 0,9 \\
$49-72$ & 0,0 & 2,6 & 0,0 & 0,9 \\
$>72$ & 0,0 & 0,0 & 0,0 & 0,0 \\
\hline
\end{tabular}


Sari Pediatri, Vol. 3, No. 2, September 2001

Tabel 4. Lama gejala demam setelah pemberian tiap dosis DPwT/hep B

\begin{tabular}{lcccc}
\hline $\begin{array}{l}\text { Saat timbul } \\
\text { gejala demam } \\
\text { (jam) }\end{array}$ & $\begin{array}{c}\text { Dosis I } \\
\mathrm{n}=47 \\
(\%)\end{array}$ & $\begin{array}{c}\text { Dosis II } \\
\mathrm{n}=38 \\
(\%)\end{array}$ & $\begin{array}{c}\text { Dosis III } \\
\mathrm{n}=39 \\
(\%)\end{array}$ & $\begin{array}{c}\text { Total } \\
\mathrm{n}=124 \\
(\%)\end{array}$ \\
\hline$<1$ & 8,5 & 10,5 & 7,7 & 8,9 \\
$1-4$ & 42,6 & 36,8 & 28,2 & 35,9 \\
$5-12$ & 31,9 & 26,3 & 30,8 & 29,7 \\
$13-24$ & 6,4 & 15,8 & 25,6 & 15,9 \\
$25-48$ & 8,5 & 5,3 & 5,1 & 6,3 \\
$49-72$ & 2,1 & 2,6 & 2,6 & 2,4 \\
$>72$ & 0,0 & 0,0 & 0,0 & 0,0
\end{tabular}

kombinasi ini, demam tinggi timbul pada 5-12 jam sedangkan (37,5\%). Lama timbul demam tinggi 1-4 jam $(36,1 \%)$. Semua pasien mendapat terapi antipiretik. (Tabel 5 dan Tabel 6)

Rewel sering timbul setelah pemberian vaksin DPwT/hep B $(31,7 \%)$ dan terutama setelah pemberian dosis kedua (36,8\%). Muntah dan diare terutama timbul setelah pemberian dosis pertama, umumnya bersifat ringan, $3-5 x$ perhari dan paling lama berlangsung 48 jam.

Reaksi lokal yang tersering adalah bengkak pada daerah suntikan (9\%) dibandingkan dengan nyeri lokal tanpa bengkak hanya terjadi pada 1 bayi $(0,5 \%)$. Bengkak pada daerah suntikan banyak terjadi setelah suntikan dosis pertama vaksin (13,5\%). Semua KIPI sembuh tanpa perlu perawatan di rumah sakit.

\section{Pembahasan}

Umumnya KIPI timbul dalam waktu 72 jam setelah pemberian suntikan vaksin. Hal ini sesuai dengan

Tabel 5. Saat timbul gejala demam tinggi setelah pemberian tiap dosis DPwT/hep B

\begin{tabular}{lcccc}
\hline $\begin{array}{l}\text { Saat timbul } \\
\text { gejala demam } \\
\text { (jam) }\end{array}$ & $\begin{array}{c}\text { Dosis I } \\
\mathrm{n}=47 \\
(\%)\end{array}$ & $\begin{array}{c}\text { Dosis II } \\
\mathrm{n}=38 \\
(\%)\end{array}$ & $\begin{array}{c}\text { Dosis III } \\
\mathrm{n}=39 \\
(\%)\end{array}$ & $\begin{array}{c}\text { Total } \\
\mathrm{n}=124 \\
(\%)\end{array}$ \\
\hline$<1$ & 0,0 & 0,0 & 0,0 & 0,0 \\
$1-4$ & 47,1 & 37,5 & 66,7 & 50,4 \\
$5-12$ & 47,1 & 62,5 & 33,3 & 47,6 \\
$13-24$ & 0,0 & 0,0 & 0,0 & 0,0 \\
$25-48$ & 5,9 & 0,0 & 0,0 & 2,0 \\
$>48$ & 0,0 & 0,0 & 0,0 & 0,0 \\
\hline
\end{tabular}

Tabel 6. Lama timbul demam tinggi setelah pemberian tiap dosis DPwT/hep B

\begin{tabular}{lcccc}
\hline $\begin{array}{l}\text { Saat timbul } \\
\text { gejala demam } \\
\text { tinggi (jam) }\end{array}$ & $\begin{array}{c}\text { Dosis I } \\
\mathrm{n}=47 \\
(\%)\end{array}$ & $\begin{array}{c}\text { Dosis II } \\
\mathrm{n}=38 \\
(\%)\end{array}$ & $\begin{array}{c}\text { Dosis III } \\
\mathrm{n}=39 \\
(\%)\end{array}$ & $\begin{array}{c}\text { Total } \\
\mathrm{n}=124 \\
(\%)\end{array}$ \\
\hline$<1$ & 5,9 & 0,0 & 0,0 & 2,0 \\
$1-4$ & 17,6 & 50,0 & 33,3 & 33,7 \\
$5-12$ & 47,1 & 25,0 & 0,0 & 24,0 \\
$13-24$ & 17,6 & 12,5 & 44,4 & 24,9 \\
$25-48$ & 5,9 & 12,5 & 22,2 & 13,5 \\
$49-72$ & 5,9 & 0,0 & 0,0 & 2,0 \\
$>72$ & 0,0 & 0,0 & 0,0 & 0,0 \\
\hline
\end{tabular}


penelitian sebelumnya di Yunani, ${ }^{5}$ Spanyol, ${ }^{6}$ dan Lithuania. ${ }^{11}$ Pada penelitian ini KIPI tersering adalah demam $(59,2 \%)$ dan rewel $(31,5 \%)$; berbeda dengan penelitian di Lithuania, ${ }^{11}$ KIPI tersering adalah reaksi lokal berupa kemerahan pada tempat suntikan (66\%) dan rewel (61\%). Pada penelitian tersebut, demam hanya timbul pada $26,7 \%$ subjek penelitian. Hampir menyerupai hasil penelitian ini, penelitian di Spanyol ${ }^{6}$ menunjukkan KIPI tersering adalah demam $(45,2 \%)$ dan rewel (39,5\%). Pada penelitian lain di Yunani, ${ }^{5}$ KIPI tersering rewel $(73,9 \%)$ dan nyeri pada tempat suntikan $(59,2 \%)$. Sedangkan pada penelitian ini, bengkak pada tempat suntikan $9 \%$ populasi penelitian dan nyeri pada tempat suntikan hanya terjadi pada 1 kasus $(0,5 \%)$. Penelitian lain di Thailand ${ }^{\circledR}$ menunjukkan KIPI tersering pada vaksinasi DPTw/HB adalah demam (64\%) dan berbeda bermakna dibandingkan dengan vaksinasi DPTw saja $(47,4 \%)(r=0,017)$.

Pada penelitian ini, demam umumnya timbul pada 1-4 jam pertama $(56,7 \%)$ dan hilang pada periode waktu tersebut (35,9\%). Penelitian di Yunani ${ }^{5}$ dan Lithuania ${ }^{11}$ menunjukkan demam timbul dan menghilang dalam 48 jam pertama pada lebih dari $90 \%$ kasus. Penelitian di Spanyol ${ }^{6}$ menunjukkan demam umumnya timbul dan menghilang dalam 24 jam pertama.

Pada penelitian ini, kejang umum terjadi pada 2 kasus dan tidak ditemukan pada penelitian lain. Kejang berhubungan dengan demam tinggi, pasca kejang pasien sadar dan tidak didapatkan gangguan neurologik. Tidak ditemukan KIPI yang memerlukan perawatan rumah sakit.

Pada penelitian ini KIPI yang didapatkan umumnya bersifat ringan sampai sedang. Sayangnya pada penelitian ini tidak terdapat kelompok kontrol sehingga tidak dapat membandingkan KIPI pada vaksin kombinasi ini dengan pemberian vaksin secara terpisah atau simultan. Penelitian dengan sampel lebih besar dan adanya kelompok kontrol perlu dilakukan lebih lanjut.

\section{Daftar Pustaka}

1. Mahoney FJ, Kane M. Hepatitis B vaccine. Dalam: Plotkin SA, Orenstein WA, penyunting. Vaccine. Edisi ke-3. Philadelphia:Saunder, 1999. h. 158-82.

2. Sub Direktorat Imunisasi, Direktorat Jendral PPM \& PLP. Petunjuk pelaksanaan program imunisasi. Edisi ke-3. Jakarta: Direktorat Jendral PPM \& PLP, 1993. h. 1-42.

3. Atkinson W, Humiston S, Wolfe C, Nelson R. Epidemiologi and prevention of vaccine-preventable diseases. Edisi ke-5. Atlanta: CDC, 1999. h. 224-46.

4. Edward KM, Decker MD, Mortimer EA Jr. Pertussis vaccine. Dalam: Plotkin SA, Orenstein WA, penyunting. Vaccines. Edisi ke-3. Philadelphia:Saunder, 1999. h. 293344.

5. Aristegui J, Garrote E, Gonzalez A, Arrate JP, Perez A, Vandepapeliere P. Immune response to a combined hepatitis $\mathrm{B}$, diphtheria, tetanus and whole-cell pertussis vaccine administered to infants at 2,4 and 6 months of age. Vaccine 1997;15:7-9.

6. Papaevangelou G, Karvelis E, Alexiou D, Kiossoglou K, Roumeliotou A, Safary A, dkk. Evaluation of a combined tetravalent diphtheria, tetanus, whole-cell pertussis and hepatitis B candidate vaccine administered to healthy infants according to a three-dose vaccination schedule. Vaccine 1995;13:175-8.

7. Lambert PH, Siegrist CA. Science, medicine \& the future: vaccine \& vaccination. BMJ 1997;315:1595-8.

8. Pichichero ME. New combination vaccine. Pediatric Clin North Am 2000;47:407-26.

9. Decker MD, Edward KM. Combination vaccine. Dalam: Plotkin SA, Orenstein WA, penyunting. Vaccines. Edisi ke-3. Philadelphia: Saunders, 1999. h. 508-30.

10. Decker MD. Edward KM. Combination vaccine: hopes and challenges. Pediatric infect Dis J 1994;13:345-8.

11. Usonis V, Bakasenas V, Taylor D, Vamdepapeliere P. Immunogenicity and reactogenicity of a combined DPTw-Hepatitis B vaccine in Lithuanian infants. Eur J Pediatric 1996;155:189-93.

12. Poovorawan Y, Theamboonlers A, Sanpavat S, Pongpunlert W, Chumdermpadetsuk S, Safary A, dkk. The immunogenicity and reactogenicity of combined tetravalents diphtheria, tetanus, pertusis and hepatitis B vaccine in infants. Proceedings of the International Symposium on Viral Hepatitis \& Liver Disaese: Molecules today, more cures tommorrow, Tokyo, May 10-14, 1993. 